\title{
ANALISIS POTENSI FINANSIAL DITREES PADA INDUSTRI SEMEN TERDAFTAR DI BURSA EFEK INDONESIA
}

\author{
Pupel Olengga. ${ }^{1}$, Fitriya Fauzi. ${ }^{2}$ \\ Magister Manajemen, Universitas Bina Darma \\ pupelollenga97@yahoo.com ${ }^{1}$, fitriya.fauzi@ binadarma.ac.id ${ }^{2}$
}

\begin{abstract}
The purpose of this research is to analyze how the potential financial distress in the cement industry are listed on the Indonesia Stock Exchange Byusing the altman zscore model and the springate model using secondary data on cement industry listed on the indonesia stock excange using quantitative descriptive analysis techniques the final result show that the financial performance analyzed using the altman z-scor model and the springate model on the cement industry listed on the indonesia stock exchange in 2013 to 2018 was in a state of no or experiencing financial difficulties. The result of the prediction of financial distrees or bankruptcy predictions are companies using the altman z-scor model in gray area and expriencing bankruptcy, namely PT. Indocement in 2017 and 2018 was in the grey area zone grey area and in 2017 experiencing financial ditrees, PT Semen Baturaja (Persero), Tbk went financial distrees in 2017 and 2018 while PT Solusi Bangun Indonesia,Tbk in 2013 to 2018 experienced financial distrees while the result of financial ditress, namely PT Solusi Bangun Indonesia, not yet in 2013 to 2018 while PT Semen Baturaja (Persero),Tbk in 2017 and 2018.
\end{abstract}

Keywords : Altman Z-score model and Springate model

\begin{abstract}
ABSTRAK
Tujuan dari penelitian ini adalah untuk menganalisis bagaimana potensi kesulitan keuangan dalam industri semen terdaftar di Bursa Efek Indonesia. Dengan menggunakan model altman z-score dan model springate menggunakan data sekunder pada industri semen yang terdaftar di Bursa Efek Indonesia menggunakan deskriptif kuantitatif. teknik analisis hasil akhir menunjukkan bahwa kinerja keuangan yang dianalisis menggunakan model altman z-scor dan model springate pada industri semen yang terdaftar di bursa efek indonesia pada 2013 hingga 2018 dalam keadaan tidak ada atau mengalami kesulitan keuangan. Hasil prediksi financial distress atau prediksi kebangkrutan adalah perusahaan yang menggunakan model altman z-scor di grey area dan mengalami kebangkrutan, yaitu PT. Indocement pada 2017 dan 2018 berada di zona abu-abu zona abu-abu dan pada 2017 mengalami kesulitan keuangan, PT Semen Baturaja (Persero), Tbk mengalami kesulitan keuangan pada 2017 dan 2018 sedangkan PT Solusi Bangun Indonesia, Tbk pada 2013 hingga 2018 mengalami kesulitan keuangan sementara hasil financial ditress, yaitu PT Solusi Bangun Indonesia, belum pada 2013 hingga 2018 sedangkan PT Semen Baturaja (Persero), Tbk pada 2017 dan 2018.
\end{abstract}

Kata Kunci : Model Altman Z-score dan model Springate 


\section{PENDAHULUAN}

Perkembangan teknologi saat ini berkembang sangat pesar sehingga sangat memerlukan keahlian dalam menganalisis laporan keuangan, hal ini menyebabkan manajer diharuskan memiliki dan mengetahui jaringan informasi seluas-luasnya agar dapat mengetahui keadaan atau kondisi perusahaan saat ini dan perkiraan kondisi perusahaan dimasa mendatang.

Informasi yang diperlukan seperti informasi akuntansi yang berbentuk laporan keuangan.Karena laporan keuangan merupakan sebuah informasi menggambarkan kinerja keuangan suatu perusahaan.

Kondisi perekonomian indonesia yang masih belum menentu mengakibatkan tingginya resiko suatu perusahaan untuk mengalami kesulitan keuangan dan kebangkrutan. Kesalahan prediksi terhadap kelangsungan operasi suatu perusahaan di masa yang akan datang dapat berakibat fatal yaitu kehilangan pendapatan atau investasi yang telah ditanamkan pada suatu perusahaan menjadi hal yang sangat dibutuhkan oleh berbagai pihak seperti pemberi pinjaman, investor, pemerintah, akuntan, dan manajemen.

Analisis kebangkrutan yang sering digunakan analisis z-score model altman dan model springate. Analisis kebangkrutan tersebut dikenal karena selain caranya mudah keakuratan dalam menentukan prediksi kebangkrutannya cukup akurat. Analisis kebangkrutan tersebut dilakukan untuk memprediksi suatu perusahaan. Industri semen mempunyai peran yang sangat penting dalam pengembangan pembangunan infrastruktur dengan kegiatan operasi produksi semen. Mulai dari produksi dan pengelolahan bahan baku sehingga produksi akhir. Sehingga hampir semua perusahan semen, baik BUMN maupun swasta, menambah kapasitas produksi dalam beberapa tahun terakhir guna mengejar kekurangan pasokan semen dipasar domestik. Permintaan semen yang terus merangkak naik ternyata tidak sejalan dengan pasokan semen harus mendatangkan bahan baku dari luar negeri. Sehingga dapat menyebabkan adanya biaya yang tinggi terhadap pembelian bahan baku dari luar negeri. Munculnya suatu permasalahan bahan baku berdampak pada kinerja suatu perusahaan manufaktur pada periode tersebut.

Sehingga perlu melakukan analisis prediksi kebangkrutan untuk mengetahui bagaimana kinerja industri semen terdaftar di Bursa Efek Indonesia dari tahun 2013-2018. Berdasarkan uraian diatas, maka penulis tertarik untuk melakukan penelitian dengan judul "Analisis Potensi Financial Distrees pada Industri Semen Terdaftar di Bursa Efek Indonesia.

\section{METODE PENELITIAN}

Penelitian ini yang digunakan adalah penilitian deskriptif. Teknik pengumpulan data yang digunakan dalam penelitian ini adalah dokumentasi, yaitu dengan mengumpulkan dan mencari langsung data-data yang berkaitan dengan penelitian ini dokumentasi merupakan catatan atau peristiwa yang sudah berlalu seperti jurnal-jurnal, seperti data-data laporan keuangan yang diambil diperusahaan (Sugiyono, 2017). Pada penelitian ini akan diteliti adalah laporan keuangan untuk mengatuhi potensi kebangkrutan Perusahaan Semen Terdaftar di Bursa Efek Indonesia.

Pada penelitian ini menggunakan model altman z-score dan model springate untuk mengetahui potensi 
kebangkrutan di Industri Semen

3. HASIL DAN PEMBAHASAN

\subsection{Analisis Kasus dan Pembahasan}

Penelitian ini menganalisa potensi Financial Distrees pada industri semen terdaftar di Bursa Efek Indonesia. Menggunakan empat laporan keuangan perusahaan berupa laporan neraca dan laporan laba rugi dari tahun 2013 sampai tahun 2018 untuk meengukur tingkat kebangkrutan dengan melakukan perhitungandengan model altman z-score dan model springate.

3.1.1 model altman z-score

Model altman z-score terdapat lima indikator dari rasio-rasio keuangan terdaftar di Bursa Efek Indonesia. yang dapat dikombinasikan untuk melihat perbedaan bangkrut tidak bangkrut.

1. Rasio X1 (Modal Kerja / Total Asset)

2. Rasio X2 (Laba Ditahan / Total Aset)

3. Rasio X3 (EBT /Total Aset)

4. Rasio X4 (Nilai Saham / Total Utang)

5. Rasio X5 (Penjualan / Total Aset)

Dibawah ini perhitungan dengan menggunakan rasio diatas pada empat perusahan semen periode dari tahun 2013 sampai tahun 2018.

Tabel 3.1.1

Perhitungan X1 sampai X5

\begin{tabular}{lclllll}
\hline Tahun & Nama perusahaan & X1 & X2 & X3 & X4 & X5 \\
\hline 2013 & $\begin{array}{c}\text { PT Solusi Bangun } \\
\text { indonesia,Tbk }\end{array}$ & $-0,0809956$ & 0,1286845 & 0,0897314 & 1,0296940 & 0,0650303 \\
& & $-0,0896175$ & 0,1021099 & 0,0539990 & 0,7315291 & 0,5513951 \\
\hline 2014 & $-0,0794193$ & 0,0844374 & 0,0202301 & 0,7195097 & 0,5333820 \\
\hline 2015 & $-0,1452904$ & 0,0537891 & 0,0200948 & 0,5484929 & 0,4785882 \\
\hline 2016 & $-0,1252288$ & 0,0155401 & 0,0420676 & 0,5395860 & 0,4780356 \\
\hline 2017 & $-0,3825897$ & 0,0280165 & 0,0520575 & 0,5474531 & 0,5559342 \\
\hline 2018 & & 0,5301624 & 0,6718898 & 0,2478706 & 1,2506988 & 0,7003828 \\
\hline 2013 & PT Indocement tunggal & & & & & 0,6922803 \\
\hline 2014 & perkasa,Tbk & 0,4440704 & 0,6856189 & 0,2359551 & 1,0538248 & 0,6439620 \\
\hline 2015 & & 0,4654802 & 0,6934411 & 0,2042290 & 1,2033366 & 0,5095057 \\
\hline 2016 & & 0,3726920 & 0,7125389 & 0,1374839 & 1,1315100 & 0,4999783 \\
\hline 2017 & & 0,3258091 & 0,6902590 & 0,0792440 & 1,0539356 & 0,5466381 \\
\hline 2018 & 0,3019281 & 0,6654171 & 0,0503886 & 0,9939787 & \\
\hline
\end{tabular}

Hasil pengolahan data 
Tabel 3.1.2

Perhitungan X1 Sampai X5

\begin{tabular}{lcccccc}
\hline 2013 & $\begin{array}{c}\text { PT Semen Indonesia } \\
\text { (Persero),Tbk }\end{array}$ & 0,1518039 & 0,5919411 & 0,2247402 & 0,2282157 & 0,7956787 \\
\hline 2014 & & 0,1857886 & 0,6229645 & 0,2066395 & 0,2202924 & 0,7864577 \\
\hline 2015 & & 0,1032554 & 0,6175547 & 0,1533537 & 0,1915000 & 0,7063199 \\
\hline 2016 & & 0,5022930 & 0,5940875 & 0,1149667 & 0,1502589 & 0,5909143 \\
\hline 2017 & & 0,1018622 & 0,5316436 & 0,0459334 & 0,2007439 & 0,5668316 \\
\hline 2018 & & 0,1525699 & 0,5543925 & 0,0802441 & 0,1113711 & 0,5998845 \\
\hline 2013 & PT Semen Baturaja & 0,7055390 & 0,1151368 & 0,1476726 & 8,2542258 & 0,4309953 \\
& (Persero), Tbk & & & & & \\
\hline 2014 & & 0,7367579 & 0,1121995 & 0,1348608 & 9,6492931 & 0,3844074 \\
\hline 2015 & & 0,5212750 & 0,1106869 & 0,1356559 & 6,3191445 & 0,4470470 \\
\hline 2016 & & 0,1249736 & 0,1174118 & 0,0799474 & 1,6166722 & 0,3485582 \\
\hline 2017 & & 0,0898704 & 0,0792477 & 0,0412911 & 1,3596239 & 0,3066050 \\
\hline 2018 & & 0,1303559 & 0,0595771 & 0,0262468 & 1,0966057 & 0,3603789 \\
\hline
\end{tabular}

Hasil pengolahan data

Berdasarkan tabel di atas dari rasio X1 sampai dengan X5 maka dapat dianalisis dengan memasukan rumus altman z-score jika setiap perusahaan tersebut mendapatkan nilai z lebih besar dari 2,99 maka perusahaan dalam keadaan sehat, jika perusahaan mendaptakan nilai 1,8 sampai dengan 2,99 maka perusahaan daalam keadaan grey area, sedangkan jika perusahaan mendapatkan nilai lebih kecil maka perusahaan dinyatakan bangkrut.

$$
\mathrm{Z}=1,2 \mathrm{X} 1+1,4 \mathrm{X} 2+3,3 \times 3+0,6 \times 4
$$

Tabel 3.1.3

Hasil Perhitungan Rumus Altman Z-score

\begin{tabular}{cccc}
\hline Nama Perusahaan & Tahun & Nilai Z & Ket \\
\hline PT Solusi Bangun Indonesia & 2013 & 1,6471969 & Bangkrut \\
\hline 2014 & 1,2039224 & Bangkrut \\
\hline 2015 & 0,6662216 & Bangkrut \\
\hline 2016 & 0,7453415 & Bangkrut \\
\hline
\end{tabular}




\begin{tabular}{lccc}
\hline & 2018 & 0,6363113 & Bangkrut \\
\hline PT Indocement Tunggal Perkarsa,Tbk & 2013 & 3,8456156 & Sehat \\
\hline 2014 & 3,5959780 & Sehat \\
\hline 2015 & 3,5693275 & Sehat \\
\hline 2016 & 3,0586893 & Sehat \\
\hline 2017 & 2,7511780 & Abu-abu \\
\hline
\end{tabular}

Hasil pengolahan data

Berdasarkan tabel perhitungan dengan model altman z-score pada perusahaan semen diatas adalah sebagai berikut:

1. PT Semen Solusi Bangun Indonesia ,Tbk

Perhitungan dengan model altman z-score PT. Solusi Bangun Indonesia,Tbk dari tahun 2013 sampai 2018 dalam keadaan bangkrut dilihat dari tahun $2013(1,6471969)$, tahun 2014 menurun (1,2039224), tahun 2015 menurun lagi (0,66622168), tahun 2016 naik menjadi $(0,7453415)$, tahun 2017 naik $(0,8899881)$, dan tahun 2018 menurun lagi $(0,636311)$.
2. PT Indocement Tunggal Prakarsa, Tbk

Hasil pengukuran pada perusahaan PT indocement Tunggal Prakarsa,Tbk dengan menggunakan model altman dari tahun 2013 sampai 2016 dikategorikan perusahaan sehat dengan pencapaian nilai $\mathrm{z}$ tahun $2013(3,8456156)$, tahun 2014 $(3,595978), \quad$ tahun 2015 $(3,5693275), \quad$ tahun 2016 $(3,0868935)$ sedangkan tahun 2017 (2,751178) dan tahun 2018 menjadi $(2,6035297)$ dalam keadaan abu-abu.

Tabel 3.1.4

Hasil Perhitungan Altman Z-score

\begin{tabular}{cccc}
\hline Nama Perusahaan & Tahun & Nilai Z & Ket \\
\hline PT Semen Indonesia (Persero), Tbk & 2013 & 2,6851330 & Sehat \\
\hline 2014 & 2,6956401 & Abu-abu \\
\hline & 2015 & 2,3157622 & Abu-abu \\
\hline PT Semen Baturaja (Persero),Tbk & 2016 & 2,4949338 & Abu-abu \\
\hline
\end{tabular}




\begin{tabular}{cccc}
\hline 2014 & 7,6602130 & Sehat \\
\hline 2015 & 5,4666899 & Sehat \\
\hline 2016 & 1,8968151 & Abu-abu \\
\hline 2017 & 1,4772912 & Bangkrut \\
\hline 2018 & 1,3447918 & Bangkrut \\
\hline
\end{tabular}

Hasil pengolahan data

Berdasarkan tabel perhitungan menggunakan model altman z-score pada perusahaan semen diatas adalah sebagai berikut :

3. PT Semen Indonesia (Persero),Tbk Perhitungan dengan menggunakan model altman z-score pada PT Semen Indonesia (Persero), Tbk dari tahun 2013 sampai 2018 dalam keadaan abu-abu sedangkan tahun 2017 perusahaan dikategorikan dalam keadaan bangkrut, dilihat dari nilai tahun $2013(2,6851330)$, tahun 2014 naik (2,6956401), tahun 2015 turun (2,3157622), tahun 2016 naik $(2,4949338)$, tahun 2017 menurun lagi (1,7053928), dan tahun 2018 naik menjadi $(1,8907305)$.

4. PT Semen Baturaja (Persero),Tbk Perhitungan menggunakan model altman z-score PT semen Baturaja (Persero),Tbk dilihat 2013 $(6,8786887), \quad$ tahun 2014 $(7,6602130), \quad$ tahun 2015 $(5,4666899), \quad$ tahun 2016 $(1,8968152)$, tahun $2017(1,4772912)$ dan tahun 2018 (1,3447918). Dari hasil tersebut perusahaan tahun 2013 sampai 2015 dikategorikan dalam keadaan sehat, tahun 2016 dalam keadaan abu-abu, sedangkan tahun 2017 daan 2018 perusahaan dikategorikan bangkrut.

\subsection{Model Springate}

Model springate menggunakan 4 rasio dalam memprediksi perusahaan sehta atau perusahaan bangkrut, dengan 4 rasio tersebut dihitung menggunakan rumus model springate yang telah ditentukan berikut perhitungan 4 rasio yang ada dibawah ini :

1. Rasio X1( Modal Kerja/Total Aset)

2. Rasio X2 (EBIT /Total Aset)

3. Rasio X3 (EBT/ Total Utang)

4. Rasio X4 (penjualan / total Aset)

Dibawah perhitungan menggunakan rasio yang terdapat dirumus model springate dari tahun 2013 sampai 2018 pada empat perusahaan semen adalah sebagai berikut: 
Tabel 3.2.1

Perhitungan Rasio X1 Sampai Rasio X4

\begin{tabular}{|c|c|c|c|c|c|}
\hline Tahun & Nama perusahaan & $\mathrm{X} 1$ & $\mathrm{X} 2$ & $\mathrm{X} 3$ & $\mathrm{X} 4$ \\
\hline \multirow{2}{*}{2013} & PT Solusi Bangun & $-0,0809956$ & 0,0897314 & 0,4097259 & 0,6503033 \\
\hline & Indonesia, Tbk & & & & \\
\hline 2014 & & $-0,0896173$ & 0,0539990 & 0,2439225 & 0,5513951 \\
\hline 2015 & & $-0,0794193$ & 0,0202301 & 0,0874569 & 0,5333826 \\
\hline 2016 & & $-0,0794193$ & 0,0200948 & 0,0323894 & 0,4785882 \\
\hline 2017 & & $-0,0145290$ & 0,0420676 & 0,1282479 & 0,4780356 \\
\hline 2018 & & $-0,3825897$ & 0,0520575 & 0,0702477 & 0,5559342 \\
\hline 2013 & $\begin{array}{l}\text { PT Indocement Tunggal } \\
\text { prakarsa,Tbk }\end{array}$ & 0,5301624 & 0,2478706 & 2,4069123 & 0,7003828 \\
\hline 2014 & & 0,4440704 & 0,2359551 & 2.0900208 & 0,6922803 \\
\hline 2015 & & 0,4654802 & 0,2042290 & 2.1001174 & 0,6439620 \\
\hline 2016 & & 0,3726920 & 0,1374839 & 1.3004917 & 0,5095957 \\
\hline 2017 & & 0,3258091 & 0,0792440 & 0,6574470 & 0,4999783 \\
\hline 2018 & & 0,3019281 & 0,0503886 & 0,3566870 & 0,5466381 \\
\hline
\end{tabular}

Hasil pengolahan data

Tabel 3.2.2

Perhitungan Rasio X1 Sampai X4

\begin{tabular}{llllll}
\hline Tahun & Nama perusahaan & \multicolumn{1}{l}{ X1 } & X2 & \multicolumn{1}{l}{ X3 } \\
\hline 2013 & PT Semen Indonesia & 0,1518039 & 0,5919411 & 1,3063198 & 0,7956787 \\
\hline 2014 & 0,1857886 & 0,6229645 & 1,3446622 & 0,7864577 \\
\hline 2015 & 0,1032554 & 0,6175547 & 0,8866124 & 0,7063119 \\
\hline 2016 & 0,0502293 & 0,5940875 & 0,6237519 & 0,5909143 \\
\hline 2017 & 0,1018622 & 0,5316436 & 0,2560202 & 0,5668316 \\
\hline 2018 & & 0,1525699 & 0,5543925 & 0,5004316 & 0,5998845 \\
\hline 2013 & PT Semen Baturaja & 0,7055390 & 0,1476726 & 2,0678574 & 0,4309953 \\
\hline 2014 & & 0,7367579 & 0,1348608 & 2,1955672 & 0,3844074 \\
\hline 2015 & & 0,5212750 & 0,1356559 & 1,8893326 & 0,4470470 \\
\hline 2016 & 0,1249736 & 0,0799474 & 1,1951933 & 0,3485582 \\
\hline 2017 & & 0,0898704 & 0,0412911 & 0,3124079 & 0,3066050 \\
\hline 2018 & 0,1303559 & 0,0262468 & 0,2284017 & 0,3603789 \\
\hline
\end{tabular}

Hasil pengolahan data 
Berdasarkan tabel diatas, empat rasio tersebut yang digunakan dalam rumus modal springate jika hasil nilai z lebih besar dari 0,862 maka perusahaan dalam keadaan zona aman sedangkan jika perusahaan nilai z lebih kecil dari 0,862 maka perusahaan tersebut dalam zona berbahaya atau sama dengan bangkrut.

$$
\mathrm{Z}=1,03 \mathrm{X} 1+3,07 \mathrm{X} 2+0,66 \mathrm{X} 3+0,4 \mathrm{X} 4
$$

Tabel 3.2.3

Hasil Perhitungan Menggunakan Model Springate

\begin{tabular}{cccc}
\hline Nama Perusahaan & Tahun & Nilai Z & Ket \\
\hline PT Solusi Bangun Indonesia & 2013 & 3,2018688 & Sehat \\
\hline 2014 & 0,4550179 & Bangkrut \\
\hline PT Indocement Tunggal Perkarsa,Tbk & 2015 & 0,2408751 & Bangkrut \\
\hline & 2016 & 0,1910778 & Bangkrut \\
\hline 2017 & 0,5339910 & Bangkrut \\
\hline 2018 & 0,0344866 & Bangkrut \\
\hline & 2014 & 2,8381004 & Sehat \\
\hline 2016 & 2,7250024 & Sehat \\
\hline & 2017 & 1,2127687 & Sehat \\
\hline
\end{tabular}

Hasil pengolahan data

Berdasarkan hasil perhitungan diatas dengan menggunakan model springate pada perusahaan semen diatas adalah sebagai berikut:

\section{PT Solusi Bangun Indonesia}

Perhitungan dengan menggunakan model springate perusahaan tahun 2013 dikategorikan dalam keadaan sehat sedangkan dari tahun 2014 sampai 2018 dikategorikan dalam keadaan bangkrut. Dilahat dari hasil tahun 2013 (3,2018688), tahun 2014 $(0,4550179), \quad$ tahun 2015
$(0,2408751), \quad$ tahun 2016 $(0,1910778)$, tahun $2017(0,555991)$, dan tahun $2018(0,0344866)$.

2. Perhitungan dengan menggunakan model springate dari tahun 2013 sampai 2018 dikategorikan perusahaan dalam keadaan sehat, dilihat dari hasil tahun 2013 $(3,1757451)$, tahun 2014 turun $(2,8381004)$, tahun 2015 turun (2,7250024), tahun 2016 turun $(1,8680752)$ meskipun mengalami penurunan perusahan tetap dalam keadaan sehat. 
Tabel 3.2.4

Hasil Perhitungan Menggunakan Model Springate

\begin{tabular}{cccc}
\hline Nama Perusahaan & Tahun & Nilai Z & Ket \\
\hline PT Semen Indonesia (Persero), Tbk & 2013 & 3,1915993 & Sehat \\
\hline & 2014 & 3,3059234 & Sehat \\
\hline & 2015 & 2,8699349 & Sehat \\
\hline & 2016 & 2,5236268 & Sehat \\
\hline PT Semen Baturaja (Persero),Tbk & 2017 & 2,1327699 & Sehat \\
\hline & 2018 & 2,4293706 & Sehat \\
\hline & 2013 & 2,7172440 & Sehat \\
\hline & 2014 & 2,7757206 & Sehat \\
\hline & 2015 & 2,3791552 & Sehat \\
\hline & 2016 & 1,3024017 & Sehat \\
\hline & 2017 & 0,5481614 & Bangkrut \\
\hline
\end{tabular}

Hasil pengolahan data

Berdasarkan perhitungan diatas menggunakan model springate pada perusahaan semen adalah sebagai berikut

1. Perhitungan dengan menggunakan model springate PT. Semen Indonesia (Persero),Tbk dikategorikan dalam perusahaan sehat, dilihat tahun 2013 $(3,1915993)$, tahun 2014 turun $(3,3059234), \quad$ tahun 2015 $(0,8699349), \quad$ tahun 2016 $(2,5236268)$, tahun 2017 turun $(2,1327699)$, dan tahun 2018 naik $(2,4293706)$.

2. Perhitungan dengan model springate pada PT Semen Baturaja (Persero),Tbk dikategorikan perusahaan sehat, dilihat tahun 2013 sampai 2016 sedangkan tahun 2017 dan 2018 perusahaan dikategorikan bangkrut, dilihat dari hasil tahun 2013 (2,3791552), tahun 2014 (2,7757206), tahun
2015 (2,3791552), tahun 2016 turun menjadi $(1,3024017)$, tahun 2017 menurun lagi $(0,5481614)$, dan tahun 2018 menurun lagi $(0,5097409)$. Dimana jika nilai $\mathrm{z}$ lebih besar dari 0,862 maka perusahaan dikategorikan sehat sedangkan jika nilai z lebih kecil dari 0,862 maka perusahaan dikategorikan bangkrut.

\section{KESIMPULAN}

Hasil dari financial distrees atau prediks i kebangkrutan dengan menggunakan metode altman z-score dan model springate keempat perusahaan ada yang mengalami kebangkrutan, yaitu:

PT. Solusi Bangun Indonesia,Tbk berada di zona kebangkrutan dari tahun 2013 sampai 2018, sedangkan dengan mengunakan model springat PT.Semen Solusi Bangun Indonesia,Tbk pada tahun 2013 berada dizona aman hal disebabkan tingginya hutang kewajiban lancar dari pada modal kerja sehingga 
mendapatkan nilai yang negatif dan kondisi keuangan yang terus menurus menurun.

PT. Semen Indonesia (Persero), Tbk berada dizona bangkrut tahun 2017 dan pada tahun 2013 sampai 2018 berada dalam zona grey area atau zona abu-abu sedangkan modal springate tahun 2013 sampai dengan tahun 2018 dalam keadaan sehat.

PT. Semen Baturaja (Persero),Tbk berada dizona bangkrut tahun 2017 dan tahun 2018, dan pada tahun 2016 PT. Semen Baturaja berda di zona grey area atau zona abu-abu,dan tahun 2013 sampai 2015 perusahaan dalam keadaan sehat. sedangkan menggunakan model springate PT. Semen Baturaja (Persero),Tbk tahun berada 2013 sampai tahun 2016 keadaan sehat, dan tahun 2017 sampai 2018 berada di zona bangkrut.

PT. Indocement Tunggal Prakarsa berada dizona grey area atau zona abuabu tahun 2017 dan 2108 dan tahun 2013 sampai 2016 perusahaan dalam keadaan sehat, sedangkan menggunakan model springate PT. Indocement Tunggal Prakasa, Tbk dalam keadaan sehat.

\section{Saran}

Berdasarkan kesimpulan diatas penulis memberikan saran sebagai berikut :

1. Perusahaan hendaknya menjaga kewajibannya pada saat jatuh tempo untuk dapat menjaga kepercayaan perusahaan sehingga dapat menarik minat kreditor dan investor.

2. Perusahaan hendaknya menjaga kestabilan modal kerja mengingat PT. Solusi Bangun Indonesia,Tbk mengalami penurunan dari tahun ke tahun berdasarkan laporan keuangan pada tahun 2013 sampai 2018 menujukan hasil negatif.

\section{REFERENSI}

\begin{tabular}{|c|c|c|}
\hline Cherryanti,Devi.2 & 3.Ana & Kinerja \\
\hline Keuangan & Melc & Model \\
\hline Zmijewski & Pada & Perusahaar \\
\hline Semen & Yang & Terdaftc \\
\hline $\begin{array}{l}\text { (BEI).Univ } \\
\text { Palembans }\end{array}$ & rrsitas & Bina Darm \\
\hline
\end{tabular}

Darsono dan Ashari.2005.Pedomana Praktisi Memahami Laporan keuangan. Andi Yogyakarta.

Fahmi, Irham.2014.Analisis Kinerja Keuangan. Alfabeta.Bandung,

Halim, Abdul dan Hanafi, Mahmud. M. 2018.Analisis laporan keuangan PT.Rajagrafindo Persada. http://www.idx.co.id

Ikatan Akuntansi Indonesia.2009. Standar Akuntansi Keuangan. Penerbit salemba empat.Jakarta.

Kasmir,2017.Analisis Laporan Keuanga $n$. PT. Rajagrafindo Persada. Jakarta.

Peter dan Yosep.2011. Analisis Kebangkrutan Dengan Metode Z-Score Altman,Spriangate, Dan Zmijewski Pada PT.Indofood Sukses Makmur,Tbk periode 20052009.Jurnal Ilimiah Akuntansi, No 04 Tahun Ke 2 JanuariApril.2011.Online Http://Www.Google. 
Praytno, Ryanto.2010.Peranan Analisis Laporan Keuangan Dalam Mengukur Keuangan Kinerja Perusahaan: Studi Kasus Pada Pt X. Jurnal Manajemen UNNUR Bandung volume 2 nol.Universitas Nurtanio Bandung.

Program pascasarjana universitas bina darma palembang.2017. Buku Pedoman Penulisan Intership. Universitas Bina Darma Palembang.
Rudiyanto.2013. Akuntansi Manajemen Untuk Pengambilan Keputusan Strategis. Erlangga

Sugiyono.2017. Metode Penelitian Kuantitatif, Kualitatif, dan $R \& D$.Bandung ALFABETA cv.

Yogyakarta Muslich, Mohammad.2010. Manajemen Keuangan Modern Bumi Aksara.Jakarta. 